\title{
Neoscytalidium dimidiatum causes leaf blight on Sansevieria trifasciata in Brazil
}

\author{
Rodrigo Pinheiro Monteles ${ }^{1} \cdot$ Enayra Silva Sousa ${ }^{1} \cdot K$ Kedma da Silva Matos ${ }^{2} \cdot$ Vinícius Soares Torquato de Brito $^{3}$. \\ Maruzanete Pereira de Melo ${ }^{4}$. José Evando Aguiar Beserra Jr ${ }^{1}$
}

Received: 16 March 2020 / Accepted: 16 April 2020 / Published online: 23 April 2020

(C) Australasian Plant Pathology Society Inc. 2020

\begin{abstract}
Sansevieria trifasciata plants showing symptoms of leaf blight were observed in Teresina City, Brazil. Based on morphology and the phylogenetic analysis of DNA sequences of the EF-1 $\alpha$ and ITS regions, two isolates of Neoscytalidium dimidiatum were identified. Pathogenicity tests showed that the isolates caused leaf blight on S. trifasciata, in addition to Sansevieria cylindrica, and fulfilled Koch's postulates. To the best of our knowledge, this report is the first to describe N. dimidiatum on Sansevieria in Brazil.
\end{abstract}

Keywords Botryosphaeriaceae $\cdot$ Leaf blight $\cdot$ Saint Jorge sword $\cdot$ Sansevieria cylindrica

The species of the genus Sansevieria (Agavaceae) are popularly known in Brazil as Saint Jorge swords. The family includes approximately 60 species of African origin, which are extremely rustic, adapting very well to the sun or shade and heat or cold (Lorenzi and Souza 2001). Several fungi, including those from the Botryosphaeriaceae family, have been reported to cause leaf disease in Sansevieria trifasciata worldwide (Farr and Rossman 2019). In Brazil, there are no reports of fungal diseases in Sansevieria spp.

In December 2018, plants of S. trifasciata var. Laurentii (De Wild.) showing symptoms of leaf blight were observed in the gardens of the Center for Agricultural Sciences of the

The sequences reported in this paper have been deposited in the GenBank under accession numbers MT026926, MT026927, MT036371 and MT036372.

José Evando Aguiar Beserra, Jr

evando@ufpi.edu.br

1 Departamento de Fitotecnia, Centro de Ciências Agrárias, Universidade Federal do Piaú (UFPI), Ininga,

Teresina, PI 64049-550, Brazil

2 Departamento de Fitotecnia, Centro de Ciências Agrárias, Universidade Federal de Roraima (UFRR), Boa Vista, RR 69310-000, Brazil

3 Curso de Ciências Biológicas, Centro de Ciências da Natureza, Universidade Estadual do Piauí (UESPI), Teresina, PI 64002-150, Brazil

4 Campus Floresta, Universidade Federal do Acre (UFAC), Cruzeiro do Sul, AC 698995-000, Brazil
UFPI, Teresina, Piauí, Brazil. Small fragments of colonized tissue were removed from the samples, disinfested in $70 \%$ ethanol for $1 \mathrm{~min}$ and $2 \%$ sodium hypochlorite for $2 \mathrm{~min}$, then transferred to sterilized distilled water and dried on sterile paper. The isolates were cultivated in potato dextrose agar culture medium (PDA) and incubated at $26 \pm 2{ }^{\circ} \mathrm{C}$ for 3 to 5 days under a 12 -h photoperiod.

The preliminary identification of the fungal isolates was based on morphological characteristics. A mycelial plug $6 \mathrm{~mm}$ in diameter taken from a 7-day-old culture was transferred to a PDA. The color and morphology of the colony were evaluated. The isolates were cultured on $2 \%$ water agar (WA) overlaid with sterilized twigs of Pinus to induce pycnidia formation and sporulation. Measurements of $30 \mathrm{se}-$ lected conidia were performed. Single-spore isolates were deposited in the culture Collection of Phytopathogenic Fungi at the Phytopathology Laboratory at the UFPI (accession numbers: COUFPI 239 and COUFPI 241).

To confirm their identification, the isolates were grown on PDA for 7 days at $26^{\circ} \mathrm{C}$ under a $12 \mathrm{~h}$ photoperiod. The aerial mycelium was scraped off the colony surface, and DNA was extracted (Moller et al. 1992). The DNA concentration was estimated visually in a $1.0 \%$ agarose electrophoresis gel stained with ethidium bromide and visualized under UV light.

The internal transcribed spacer (ITS) region was amplified with the primers ITS1 and ITS4 (White et al. 1990), and transcription elongation factor $1-\alpha(E F 1-\alpha)$ was amplified with the primers 728F (Carbone and Kohn 1999) and EF2R (O'Donnell et al. 1998). The PCR products were purified 
Table 1 Isolates and DNA sequences data used in phylogenetic analysis

\begin{tabular}{|c|c|c|c|c|c|c|}
\hline \multirow[t]{2}{*}{ Species } & \multirow[t]{2}{*}{ Isolate } & \multirow[t]{2}{*}{ Host } & \multirow[t]{2}{*}{ Location } & \multirow[t]{2}{*}{ Reference } & \multicolumn{2}{|c|}{$\begin{array}{l}\text { GenBank accession } \\
\text { numbers }\end{array}$} \\
\hline & & & & & ITS & EF- $1 \alpha$ \\
\hline Neofusicoccum mangiferae & CMW7024 & Mangifera indica & Australia & Slippers et al. 2005 & AY615185 & DQ093221 \\
\hline Neofusicoccum vitifusiforme & STE-U5252 & Vitis vinifera & South Africa & van Niekerk et al. 2004 & AY343383 & AY343343 \\
\hline Neoscytalidium dimidiatum & B3 & Sansevieria trifasciata & Malaysia & Kee et al. 2017 & MF580797 & - \\
\hline N. dimidiatum & *CBS 499.66 & M. indica & Mali & Phillips et al. 2013 & KF531820 & KF531798 \\
\hline N. dimidiatum & COUFPI 239 & S. trifasciata & Teresina, Brazil & Present study & MT026926 & MT036371 \\
\hline N. dimidiatum & COUFPI 241 & S. trifasciata & Teresina, Brazil & Present study & MT026927 & MT036372 \\
\hline Neoscytalidium novaehollandiae & CBS122071 & Crotalaria medicaginea & Australia & Pavlic et al. 2008 & EF585540 & EF585580 \\
\hline N. novaehollandiae & CBS122072 & Adansonia gibbosa & Australia & Pavlic et al. 2008 & EF585535 & EF585581 \\
\hline Neoscytalidium orchidacearum & MFLUCC 12-0533 & Orchid & Thailand & Huang et al. 2016 & KU179865 & - \\
\hline
\end{tabular}

*Epitype (B3 = Culture Collection Unit, Department of Plant Pathology, School of Biological Sciences, Universiti Sains Malaysia; CBS = CBS-KNAW Fungal Biodiversity Centre, Utrecht, The Netherlands; CMW = Culture collection of the Forestry and Agricultural Biotechnology Institute, University of Pretoria, Pretoria, South Africa; MFLUCC = Mae Fah Luang University Culture Collection; STE-U = Culture collection of the Department of Plant Pathology, University of Stellenbosch, South Africa)

and sequenced by Macrogen Inc. (Seoul, South Korea). Additional sequences of Botryosphaeriaceae isolates were obtained from GenBank (Table 1). The obtained sequences were aligned using the multiple sequence alignment program MUSCLE® implemented in MEGA v. 8 software. The resulting alignment was deposited in TreeBASE under accession number ID25814. Bayesian inference analyses were performed using the Monte Carlo chain method. Mr. Modeltest 2.3 (Posada and Buckley 2004) was used to determine the evolutionary model of the nucleotides that best fit the data;
Fig. 1 Neoscytalidium dimidiatum pathogenic to Sansevieria trifasciata. (a) Necrosis symptoms observed in the field. (b) Symptomatic plant seven days after inoculation with the COUFPI 239 isolate. (c) Colony after four days of incubation in PDA medium at $\pm 26^{\circ} \mathrm{C}$ under a $12 \mathrm{~h}$ photoperiod. (d-f) Different forms and pigmentation in chain arthroconidia
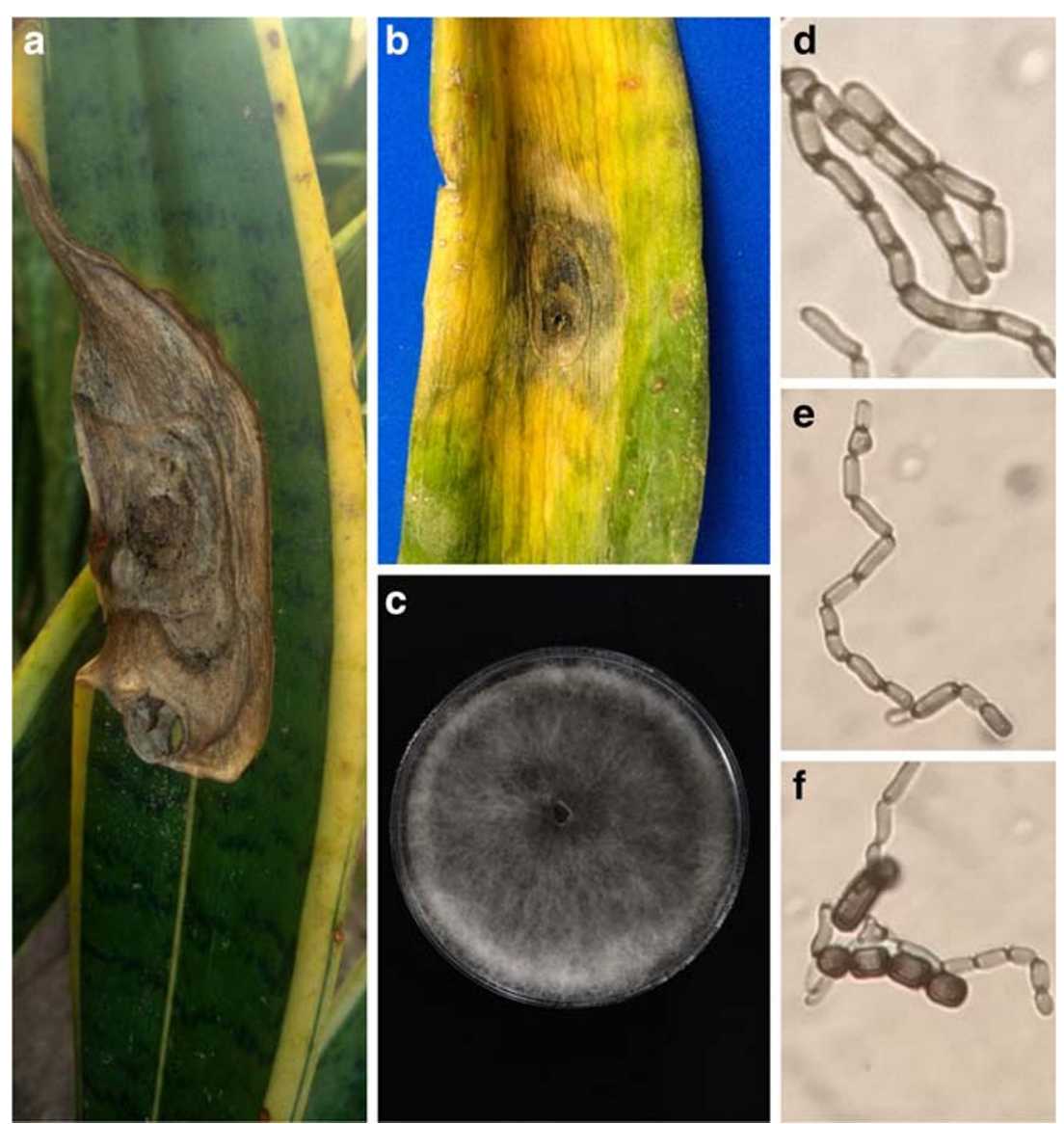
Fig. 2 Bayesian phylogenetic tree of ITS-5.8S rDNA and EF- $1 \alpha$ sequences showing the phylogenetic relationships among species of Neoscytalidium based on the evolutionary models HKY for ITS and the HKY + I for EF$1 \alpha$. Posterior probability values are indicated above the nodes. The isolates used in this study are highlighted in bold. The tree is rooted with Neofusicoccum mangiferae and Neofusicoccum vitifusiforme

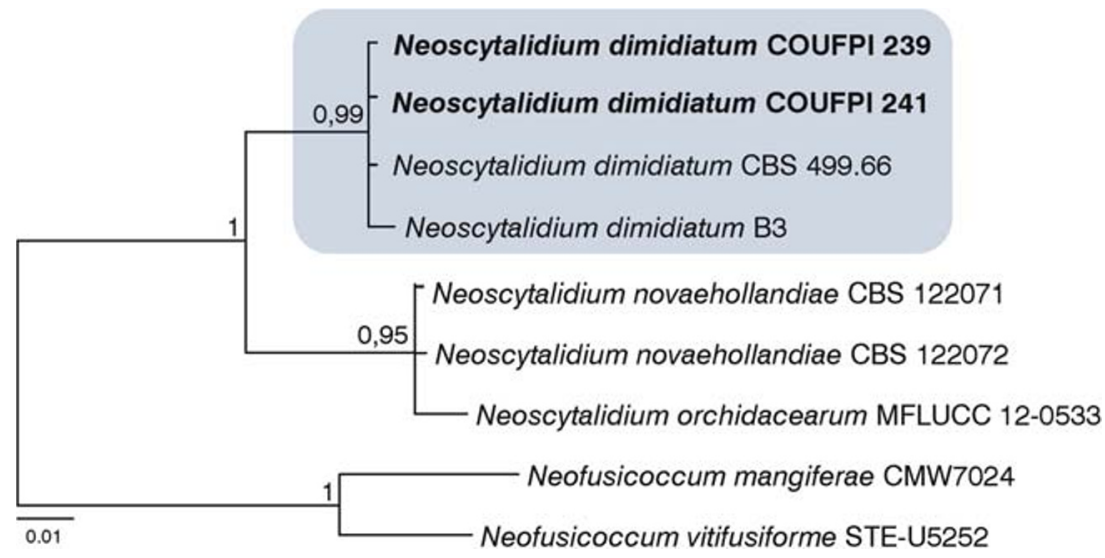

the models used in the phylogenetic analyses were HKY for ITS and HKY + I for EF- $1 \alpha$.

Phylogenetic analysis was performed at the CIPRES web portal (Miller et al. 2010) using MrBayes version v. 3.2 (Ronquist et al. 2011). Markov chains were run simultaneously from random trees to $10,000,000$ generations. Trees were sampled every 1000th generation for a total of 10,000 trees. The first 2500 trees were discarded as burn-in in each analysis. The sequences obtained in this study were deposited in GenBank (Table 1).

To confirm pathogenicity, isolates were cultured on PDA for 4 days at $26{ }^{\circ} \mathrm{C}$ under a 12 -h photoperiod before inoculation onto 6-month-old plants of $S$. trifasciata var. Laurentii, Hahnii, Prain, and Sansevieria cylindrica. Plants were inoculated with sterile toothpicks, inserting fungal structures in the basal, middle and apical regions of the leaves. Plant inoculated with non-infected toothpicks were used as a negative control. After inoculation, the plants were maintained in a moist chamber constructed using plastic bags for $24 \mathrm{~h}$. These bags were then removed, and the plants were kept in an environment with the temperature controlled at $26 \pm 2{ }^{\circ} \mathrm{C}$. Disease development was observed until 30 days after inoculation. The experiment was repeated twice, and five replicates of each variety/species were tested for each isolate.

The isolates were pathogenic to $S$. trifasciata var. Laurentii, Hahnii, Prain, and S. cylindrica. Leaf blight symptoms similar to the symptoms found in the field (Fig. 1a) were observed four days after inoculation, starting with dark lesions around the inoculation point (Fig. 1b). No symptoms were observed on the control plants. The isolates were consistently recovered from the inoculated plants.

Based on multigene phylogenetic analysis, the isolates were identified as Neoscytalidium dimidiatum. Isolates COUFPI 239 and COUFPI 241 were grouped with the reference isolate of $N$. dimidiatum (CBS 499.66) with high support $($ Bayesian posterior probability $=0.99)($ Fig. 2$)$.

The isolate cultures presented a white color and cotonose mycelium, were denser at the center and border. After the third day, the colonies became light gray, and they later became dark gray (Fig. 1c), showing the reverse pattern of the same color. The hyphae were light brown and septate. The arthroconidia were diverse in morphology and coloration; 0 1 septum was observed, and most were ovoid and light brown (Fig. 1f). Arthroconids were arranged in chains (Fig. 1d, e). The arthroconids were 10.04 to $15.94 \times 7.13$ to $9.92 \mu \mathrm{m}$. Pycnidia were observed after 10 days of incubation.

Neocytalidium dimidiatum has been reported to cause leaf blight in S. trifasiata in Malaysia (Kee et al. 2017). In Brazil, $N$. dimidiatum has been reported to cause root rot in physic nut and cassava (Machado et al. 2012; Mello et al. 2018), black root rot in cassava (Machado et al. 2014), dieback in grapevine and mango (Correia et al. 2016; Marques et al. 2013). Our study provides the first report of leaf blight on Sansevieria trifasciata in Brazil caused by Neoscytalidium dimidiatum.

Acknowledgements ESS is recipient of a Coordenação de Aperfeiçoamento de Pessoal de Nível Superior (CAPES) scholarship and JEABJ is recipient of PQ fellowship from Conselho Nacional de Desenvolvimento Científico e Tecnológico (CNPq).

\section{Compliance with ethical standards}

Disclosure of potential conflicts of interest We declare that the authors have no conflicts of interest.

Ethical approval This article does not contain any studies with human participants or animals performed by any of the authors.

\section{References}

Carbone I, Kohn LM (1999) A method for designing primer sets for speciation studies in filamentous ascomycetes. Mycologia 9:553556

Correia KC, Silva MA, Netto MSB, Vieira WAS, Câmara MPS, Michereff SJ (2016) First report of grapevine dieback caused by Neoscytalidium hyalinum in Brazil. Plant Dis 100:213-213

Farr DF, Rossman AY (2019) Fungus-host distribution database, Systematic Mycology and Microbiology Laboratory, ARS, USDA Available at: http://ntars-gringov/fungaldatabases/Cited 1 Dec 2019 
Huang SK, Tangthirasunun N, Phillips AJL, Dai DQ, Wanasinghe DN, Wen TC, Bahkali AH, Hyde KD, Kang JC (2016) Morphology and phylogeny of Neoscytalidium orchidacearum sp. nov. (Botryosphaeriaceae). Mycobiology 44:79-84

Kee YJ, Suhaimi NN, Zakaria L, Mohd MH (2017) Characterisation of Neoscytalidium dimidiatum causing leaf blight on Sansevieria trifasciata in Malaysia. Australas Plant Dis Notes 12:1-4

Lorenzi H, Souza HM (eds) (2001) Plantas ornamentais no Brasil. Instituto Plantarum, Nova Odessa, 1088p

Machado AR, Pinho DB, Dutra DC, Pereira OL (2012) First report of collar and root rot of physic nut (Jatropha curcas) caused by Neoscytalidium dimidiatum in Brazil. Plant Dis 96:1697

Machado AR, Pinho DB, Oliveira SAS, Pereira OL (2014) New occurrences of Botryosphaeriaceae causing black root rot of cassava in Brazil. Trop Plant Pathol 39:464-470

Marques MW, Lima NB, Morais MA Jr, Michereff SJ, Phillips AJL, Câmara MPS (2013) Botryosphaeria, Neofusicoccum, Neoscytalidium and Pseudofusicoccum species associated with mango in Brazil. Fungal Divers 61:195-208

Mello JF, Brito ACQ, Motta CMS, Vieira JCB, Michereff SJ, Machado AR (2018) First report of Neoscytalidium dimidiatum causing root rot in sweet potato in Brazil. Plant Dis 103:373

Miller MA, Pfeiffer W, Schwartz T (2010) Creating the CIPRES Science Gateway for inference of large phylogenetic trees. 1-8. In: Proceedings of the Gateway Computing Environments Workshop (GCE), 14 Nov. 2010, New Orleans, LA

Moller EM, Bahneg G, Sandermann H, Geiger HH (1992) A simple and efficient protocol for isolation of high molecular weight DNA from filamentous fungi, fruit bodies and infected plant tissues. Nucleic Acids Res 22:6115-6116
O'Donnell K, Kistler HC, Cigelnik E, Ploetz RC (1998) Multiple evolutionary origins of the fungus causing Panama disease of banana: concordant evidence from nuclear and mitochondrial gene genealogies. P Nat Acad Sci 95:2044-2049

Pavlic D, WingfieldMJ BP, Slippers B, Hardy GE, Burgess TI (2008) Seven new species of the Botryosphaeriaceae from baobab and other native trees in Western Australia. Mycologia 100:851-866

Phillips AJ, Alves A, Abdollahzadeh J, Slippers B, Wingfield MJ, Groenewald JZ, Crous PW (2013) The Botryosphaeriaceae: genera and species known from culture. Stud Mycol 76:51-167

Posada D, Buckley TR (2004) Model selection and model averaging in phylogenetics: advantages of Akaike information criterion and Bayesian approaches over likelihood ratio tests. Syst Biol 53:793808

Ronquist F, Teslenko M, van der Mark P, Ayres D, Darling A, Höhna S, Larget B, Liu L, Suchard MA, Huelsenbeck JP (2011) MrBayes 3.2: efficient Bayesian phylogenetic inference andmodel choice across a large model space. Syst Biol 61:539-542

Slippers B, Johnson GI, Crous PW, Coutinho TA, Wingfield BD, Wingfield MJ (2005) Phylogenetic and morphological reevaluation of the Botryosphaeria species causing diseases of Mangifera indica. Mycologia 97:99-110

van Niekerk JM, CrousPW GJZ, Fourie PH, Halleen F (2004) DNA phylogeny, morphology and pathogenicity of Botryosphaeria species on grapevines. Mycologia 96:781-798

White TJ, Bruns T, Lee S, Taylor JW (1990) Amplification and direct sequencing of fungal ribosomal RNA genes for phylogenetics. In: Innis MA, Gelfand DH, Sninsky JJ, White TJ (eds) PCR protocols: a guide to methods and applications. Academic Press Inc, New York, pp 315-322 